ACTA UNIVERSITATIS LODZIENSIS

FOLIA LITTERARIA POLONICA 2(32) 2016

http://dx.doi.org/10.18778/1505-9057.32.02

Magdalena Hodak

\title{
Prawne konsekwencje stosowania stylu satyrycznego
}

Tytuł artykułu Prawne konsekwencje stosowania stylu satyrycznego może zaniepokoić. To efekt zamierzony. Sama treść wywodu nie ma jednak wywoływać lęku przed tworzeniem form satyrycznych, ale wyczulić na sposób podejścia wymiaru sprawiedliwości do publikacji o charakterze satyrycznym. Może ono wynikać z braku doświadczenia sądów w ocenianiu szczególnej materii, jaką stanowi przekaz satyryczny.

Czy z satyrą jednak potrafią obchodzić się dziennikarze? Piotr Wasilewski, pisząc o satyrze, zauważa, że „nie ma przesady w porównaniu jej do swoistej broni, jest bowiem niebezpieczna, czasem obosieczna - i na pewno trzeba umieć się z nią obchodzić". . Autor podkreśla przy tym stosunkowo niewielką liczbę orzeczeń i wypowiedzi doktryny na temat satyry oraz znikomą wręcz liczbę analiz i opracowań teoretycznych.

Swoje stanowisko na sformułowany $\mathrm{w}$ tytule temat przedstawię jako teoretyk i praktyk. Jestem autorką pracy doktorskiej, w której wyodrębniłam i opisałam satyryczne gatunki prasowe ${ }^{2}$. Rozdział piąty dysertacji został poświęcony zdefiniowaniu i omówieniu stylu satyrycznego (wcześniej nie był on wyeksponowany). Z kolei jako dziennikarka i redaktor naczelna lokalnych pism spotykałam się z rozmaitymi reperkusjami po opublikowaniu form satyrycznych, pozyskując przy okazji szerszą wiedzę na temat sądowych bojów z satyrą na pierwszym planie.

Styl satyryczny wykształcony został w twórczości literackiej, plastycznej, widowiskowej. Powstał z potrzeby krytycznego spojrzenia na rzeczywistość, używany jest do komentowania bieżących wydarzeń czy oceny osób, środowisk³

* Dr, e-mail: magdalena.hodak@gmail.com; Uniwersytet Łódzki, Wydział Filologiczny, Katedra Dziennikarstwa i Komunikacji Społecznej; ul. Pomorska 171/173, 90-236 Łódź.

${ }^{1}$ P. Wasilewski, Wolność prasowej wypowiedzi satyrycznej. Studium cywilistyczne na tle porównawczym, Wolters Kluwer, Warszawa 2012, s. 13.

${ }^{2}$ M. Hodak, Satyryczne gatunki prasowe po 1989 roku, niepublikowana praca doktorska napisana na Wydziale Filologicznym UŁ pod kierunkiem prof. dr hab. Barbary Bogołębskiej, Łódź 2015.

${ }^{3}$ Wniosek na podstawie definicji satyry [w:] Stownik rodzajów i gatunków literackich, red. G. Gazda, wyd. 2, Wydawnictwo Naukowe PWN, Warszawa 2012, s. 986-990. 
W swojej dysertacji wykazałam, iż w stylu satyrycznym pojawiają się elementy stylu potocznego, retorycznego czy artystycznego z charakterystycznymi dlań składnią czy słownictwem. Obecna, a może raczej wszechobecna, jest hiperbolizacja, ironia, parodia czy groteska.

W twórczości plastycznej o charakterze satyrycznym, także tej funkcjonującej w prasie, styl satyryczny tworzony jest poprzez wydłużane kreski, zachwianie proporcji w karykaturach i fotomontażach (np. wielka głowa, długi nos) ${ }^{4}$.

W przypadku gatunków satyrycznych często spotykane jest łączenie przedstawienia ikonicznego z tekstem, dzieje się tak np. w tzw. dymkach, zwanych też chmurkami.

Do satyrycznych gatunków prasowych zaliczyć należy komunikaty wizual$n e^{5}$ i tekstowe. W pierwszej grupie mieszczą się np. rysunki, komiksy, fotomontaże, zdjęcia z podpisem i tytułem, w drugiej: felieton, przeglądy prasy (rubryka Polityka i obyczaje w „Polityce”) i wydarzeń (np. rubryka Mea pulpa Kuby Wojewódzkiego w „Polityce”) oraz goszczące w mediach literackie formy satyryczne, a więc fraszki, aforyzmy, wiersze, piosenki, szopki noworoczne.

Szczepan Sadurski, wybitny polski satyryk ${ }^{6}$, napisał:

W ostatnich latach polskie sądy i prokuratura coraz częściej decydują o tym, co w twórczości satyrycznej jest zabawne, a co nie jest. Coraz częściej dochodzi do spięć na linii: twórczość satyryczna - prawo. Kiedyś był urząd cenzury, teraz każdy satyryk może mówić, pisać i drukować, co zechce, a funkcje cenzury przejęły sądy i prokuratura, a także KRRiTV. Czasami w roli cenzora występują poprawne politycznie media? ${ }^{7}$.

Przyjrzyjmy się narzędziom prawnym wykorzystywanym do stosowania cenzury nowego typu. Urażony bohater satyrycznego tekstu może na podstawie artykułu 212 Kodeksu karnego ${ }^{8}$ sporządzić prywatny akt oskarżenia, a jeśli jest funkcjonariuszem publicznym, napisać doniesienie o możliwości popełnienia przestępstwa zniesławienia i dostarczyć je do prokuratury. Ściganie za zniesławienie przez prokuraturę jest z powodu represyjności mocno kontrowersyjne, za zniesławienie można bowiem trafić do więzienia.

\footnotetext{
${ }^{4}$ Pojęcie karykatury w najwęższym znaczeniu odnosi się do sztuk plastycznych. Definicja [w:] K. Zwolińska, Z. Malicki, Maty słownik terminów plastycznych, Wiedza Powszechna, Warszawa 1974, s. $155-156$.

${ }^{5} \mathrm{Na}$ temat satyrycznych form wizualnych zob. A. Kozieł, Publicystyka wizualna $w$ prasie: karykatura, rysunek satyryczny, fotomontaż, [w:] Komunikacja wizualna w prasie $i$ w mediach elektronicznych, red. K. Wolny-Zmorzyński, W. Furman, J. Snopek, K. Groń, Poltext, Warszawa 2013.

${ }^{6}$ Szczepan Sadurski to zdobywca m.in. Złotej Szpilki'86, artysta wystawia swoje prace na całym świecie.

${ }^{7}$ S. Sadurski, Satyra i paragraf, http://www.sadurski.com/satyra/paragraf.htm [dostęp: 10.02.2016].

${ }^{8}$ Ustawa z 6 czerwca 1997 r., Kodeks karny (Dz. U. z 1997 r. Nr 88 poz. 553 ze zm.)
} 
Kampanię społeczną,„Wykreśl 212 kk” - na rzeczzniesienia odpowiedzialności karnej za zniesławienie - rozpoczęły we wrześniu 2011 roku Helsińska Fundacja Praw Człowieka, Izba Wydawców Prasy oraz Stowarzyszenie Gazet Lokalnych ${ }^{9}$. Artykuł 212 nadal figuruje, niestety, w Kodeksie karnym. Parlamentarzystom różnych opcji brakuje woli, by usunąć zapis, zwycięża pokusa posiadania „bata” na krytyków, wywierania presji na dziennikarzy. Niezależnie bowiem od ostatecznego rozstrzygnięcia sprawy, sama upokarzająca procedura karna (przeprowadzanie wywiadu środowiskowego, a nawet kierowanie na badania psychiatryczne) może zniechęcać śmiałków (dziennikarzy czy osoby prywatne publikujące w internecie) do kierowania krytyki, także tej prześmiewczej, w stronę władzy. To właśnie prześmiewczość najbardziej denerwuje krytykowanych polityków.

Osoby piastujące najwyższe stanowiska publiczne (prezydent, premier, marszałkowie Sejmu i Senatu) są dodatkowo chronione. Na straży ich dobrego imienia stoi artykuł 135 par. $2 \mathrm{kk}^{10}$, który przewiduje karę trzech lat pozbawienia wolności za znieważenie prezydenta, np. poprzez publikację znieważających treści w mediach ${ }^{11}$.

Z kolei za znieważenie lub poniżenie konstytucyjnego organu Rzeczypospolitej Polskiej (m.in. Sejm, Senat, prezydent, Rada Ministrów, prezes Rady Ministrów, trybunały i sądy, rzecznik praw obywatelskich) grozi na mocy artykułu 226 par. $3 \mathrm{kk}^{12}$ grzywna, kara ograniczenia wolności albo pozbawienia wolności do lat dwóch; czyny te ścigane są z urzędu.

Zdarza się, że aparat państwowy reaguje wyjątkowo gorliwie. Zdjęcie dwóch kaczek w wodzie z podpisem „A teraz kochani wyborcy... pocałujcie nas w kupry" (Fot. 1) rozpoczęło dyskusję na temat granic satyry i krytyki władzy publicznej. Prokuratura wszczęła śledztwo przeciwko emerytowi, który rozpowszechniał zdjęcie e-mailem ${ }^{13}$. W tym wypadku odwulgaryzowanie związku frazeologicznego „całować w dupę” okazało się bardziej kontrowersyjne z powodu aluzji do Lecha i Jarosława Kaczyńskich ${ }^{14}$.

\footnotetext{
${ }^{9}$ Nowa kampania spoteczna: ,,Wykreśl 212 kk”, http://wiadomosci.onet.pl/kraj/nowa-kampania-spoleczna-wykresl-212-kk/hdd1b [dostęp: 29.01.2016].

${ }^{10}$ Ustawa z 6 czerwca 1997, Kodeks karny (Dz. U. z 1997 r. Nr 88 poz. 553).

${ }^{11}$ Pod koniec lutego 2016 r. w Sejmie pojawiła się inicjatywa partii Nowoczesna, by znieść ów przepis.

${ }^{12}$ Ustawa z 6 czerwca 1997 r. Kodeks karny (Dz. U. z 1997 Nr 88 poz. 553).

${ }^{13}$ Internauta ,represjonowany” za żart z Kaczyńskich. Szef PO Donald Tusk powiedziat, że internauta z Elblaga - który rozestat pocztq elektronicznq..., http://wiadomosci.onet.pl/tablica/internautarepresjonowany-za-zart-z-kaczynskich-sz,1666,270154,41022122,watek.html [dostęp: 29.01.2016].

${ }^{14} \mathrm{~W}$ dalszej części wywodu przedstawiony zostanie przykład dosłownego użycia $\mathrm{W}$ formie satyrycznej frazeologizmu „mieć w dupie”.
} 


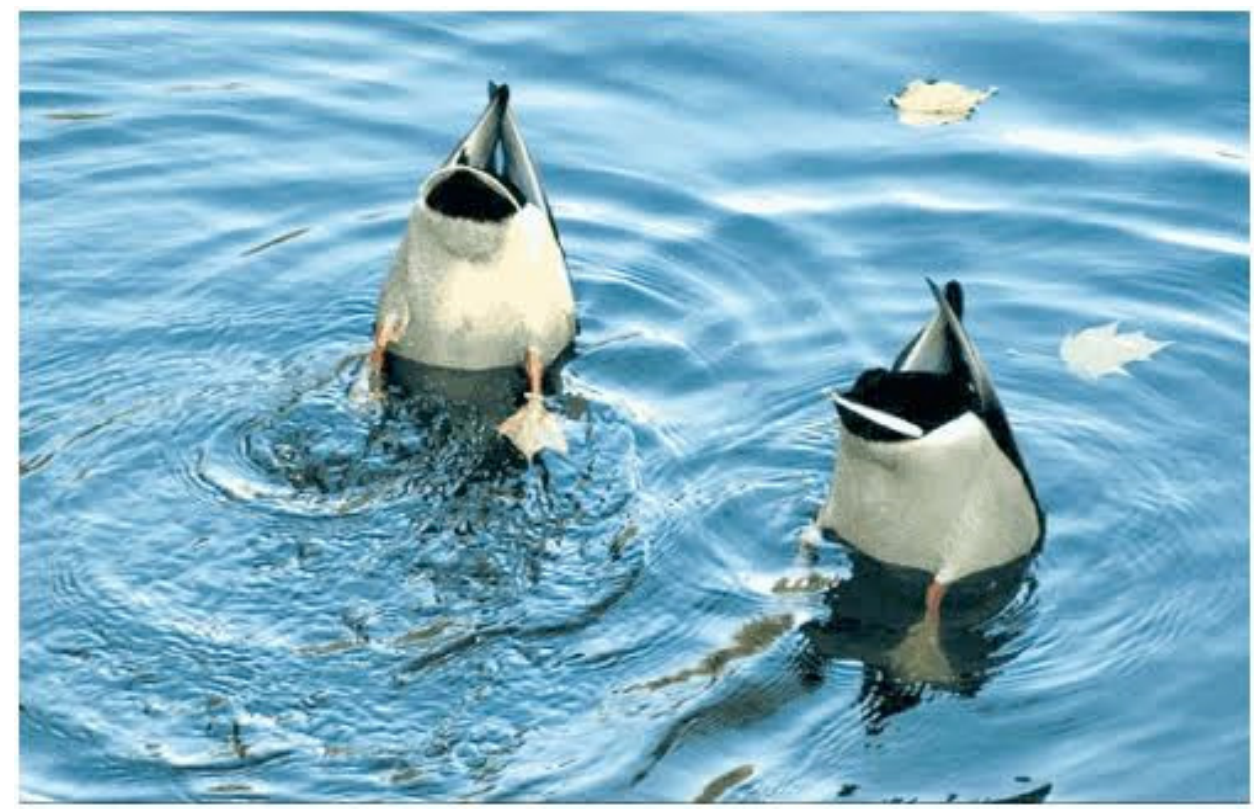

Fot. 1

Źródto: www.demotywatory.pl.

Jakkolwiek satyra opiera się na przesadzie i fikcji, a zwrot „pocałujcie nas w kupry" wypowiadany przez ptaki wyczerpuje znamiona stylu satyrycznego, to słowo „przesada” przestaje być wystarczające do określenia nadgorliwości organów ścigania.

Z kolei Kodeks cywilny oferuje dotkniętym artykuły 23 i $24^{15}$, które dotyczą ochrony dóbr osobistych.

$Z$ drugiej strony na straży wolności wypowiedzi stoi art. 54 ust. 1 Konstytucji. Jest ona także gwarantowana przez art. 10 ust. 1 europejskiej Konwencji o ochronie praw człowieka i podstawowych wolności z dnia 4 listopada 1950 roku. Jak głosi art. 1 ustawy Prawo prasowe z dnia 26 stycznia 1984 roku: „Prasa, zgodnie z Konstytucją Rzeczypospolitej Polskiej, korzysta z wolności wypowiedzi i urzeczywistnia prawo obywateli do ich rzetelnego informowania, jawności życia publicznego oraz kontroli i krytyki społecznej".

O ochronie prawa do krytyki mówi art. 41 ustawy Prawo prasowe. Czytamy w nim, że:

publikowanie rzetelnych, zgodnych z zasadami współżycia społecznego ujemnych ocen dzieł naukowych lub artystycznych albo innej działalności twórczej, zawodowej lub publicznej służy realizacji zadań określonych w art. 1

${ }^{15}$ Ustawa z 23 kwietnia 1964 roku Kodeks cywilny (Dz. U. Nr 16 poz. 93 ze zm.). 
i pozostaje pod ochroną prawa; przepis ten stosuje się odpowiednio do satyry i karykatury ${ }^{16}$.

Zapisy prawa cywilnego nie są represyjne, ale wykorzystują je osoby publiczne, by zniechęcić wydawców do publikowania krytycznych treści, a w rezultacie ograniczyć działalność misyjną dziennikarzy, polegającą na „patrzeniu władzy na ręce" i wyrażaniu krytyki także przy użyciu narzędzi satyrycznych. Kierowanie pozwu wiąże się nie tyko z perspektywą zapłacenia zadośćuczynienia, ale już na początku z potrzebą wynajęcia adwokata. To dla niewielkich wydawnictw może być uciążliwe, dlatego decydując się na określoną linię redakcyjną pisma, trzeba mieć - aby móc ją realizować - zarezerwowane odpowiednie środki finansowe. W przeciwnym razie gazeta szybko uzależni się od władzy, stając się wręcz jej tubą propagandową.

Nie ma statystyk dotyczących spraw sądowych, w których pozwani poczuli się urażeni satyrą. Z ogólnego oglądu wynika, że autorzy satyry mieli naruszyć cześć powodów poprzez epitety, fikcyjne wypowiedzi czy fotomontaże.

Stanisław Tym jako felietonista „Wprost” ocenił prokuratora prowadzącego sprawę domniemanego szpiegostwa Józefa Oleksego. Napisał, że prokurator "ma osobowość nieskomplikowaną, prostolinijną i czystą, przyjazną Oleksemu", nazwał oskarżyciela: „prokuratorzyną”, „zezowatym umysłowo prokuratorem” i „przypadkowym prokuratorem”. Sąd w Suwałkach uznał, że autor przekroczył granice dozwolonej satyry w felietonach we „Wprost”, ale umorzył sprawę z uwagi na znikomą szkodliwość społeczną czynu. Tym powiedział po rozprawie, że skoro to, co pisze, kwalifikuje jego teksty jako satyrę, to czuje zawód z powodu wyroku, w którym sąd uznał to za szkodliwe społecznie, nawet w znikomym stopniu. „Satyra, którą stosuję, przejaskrawia i wyolbrzymia ludzkie wady, czasem jest kpiną, inwektywą, a nawet szyderstwem. Satyra dopuszcza ich użycie i tak czyniłem od wielu lat"17.

Sąd Okręgowy w Warszawie orzekł, że Jerzy Urban musi przeprosić premiera Donalda Tuska za primaaprilisowy żart tygodnika „Nie”18. Tygodnik zrelacjonował rzekomo podsłuchaną, naszpikowaną wulgaryzmami, rozmowę premiera z innymi VIP-ami na trybunie honorowej Stadionu Narodowego podczas meczu Polska - Ukraina. W tekście pojawiły się wypowiedzi przypisane m.in.: Tuskowi, Lechowi Wałęsie, Jolancie Kwaśniewskiej. Choć znaczna część opinii publicznej oceniła żart jako żenujący i niesłużący społecznemu interesowi, reakcja premiera uznana została za mocno przesadzoną.

\footnotetext{
${ }^{16}$ Ustawa z 26 stycznia 1984 roku Prawo prasowe (Dz. U. 1984 Nr 5 poz. 24 ze zm.).

${ }^{17}$ Jakie granice satyry?, http://www.wprost.pl/ar/20125/Jakie-granice-satyry/ [dostęp: 30.01.2016].

${ }^{18}$ Koniec procesu Tusk - Urban. Naczelny „Nie” obśmiat wyrok, http://wiadomosci.dziennik. $\mathrm{pl} /$ media/artykuly/440852,koniec-procesu-tusk-urban.html [dostęp: 4.02.2016].
} 
Wyznaczaniu granic satyry nie służą sprzeczne orzeczenia zapadające przed polskimi sądami. Raz fakt, że wypowiedzi padają w programie satyrycznym, jest brany pod uwagę, a w innym przypadku już nie. Co ciekawe, może to dotyczyć tego samego programu.

W programie Poranny WF (radio Eska Rock), nawiązując do wygranego przez Ukrainę meczu ze Szwecją podczas Euro 2012, Kuba Wojewódzki mówił m.in., że „zachował się jak prawdziwy Polak” i „wyrzucił swoją Ukrainkę”. Michał Figurski dodał: „Ja po złości jej dzisiaj nie zapłacę” oraz: „Powiem ci, że gdyby moja była chociaż odrobinę ładniejsza, to jeszcze bym ją zgwałcił". Wyrok: 50 tys. $\mathrm{z}^{19}$.

Figurski i Wojewódzki zostali również oskarżeni przez prokuraturę o znieważenie osoby ze względu na przynależność rasową i narodową. Chodziło o żart z telefonem „buszmeńskiej sieci dla czarnych” do Murzyna - rzecznika Głównego Inspektoratu Transportu Drogowego, dr. Alvina Gajadhura ${ }^{20}$. Sąd uznał, że choć wypowiedź była obraźliwa, to nie wypełniła znamion czynu zabronionego, gdyż był to program satyryczny.

Jak widać - sądy nie pomagają w jednoznacznym wytyczaniu granic satyry, a argument, iż każda sprawa jest indywidualna, nie usprawiedliwia jaskrawych rozbieżności w orzecznictwie. Jaka jest zatem granica satyry?

Być może takiej granicy należy szukać pomiędzy językiem nienawiści a formami satyrycznego wyrazu. Ewa Łętowska rozróżnia tzw. język nienawiści od form satyrycznego wyrazu, przy pomocy których nadawca przekazuje swój punkt widzenia, powodując śmiech i refleksję. Jak przekonuje:

„Złe słowo" to słowo szczujące, raniące, poniżające, szydercze, nawołujące do czynów gwałtownych. Ale też - przyznam - nie zaliczam do tej kategorii prześmiewczej satyry czy karykatury (nawet ostrej - dlatego nie przekonuje mnie konieczność interwencji we wczesnych godzinach rannych $\mathrm{w}$ domu internauty umieszczającego satyryczne rysuneczki czy filmiki). Nie przekonuje mnie karanie internauty za zniewagę prezydenta, podobnie jak karanie piosenkarki za żart z Biblii ${ }^{21}$.

${ }^{19}$ Za żarty z Ukrainek Eska Rock zapłaci 50 tys. zt. Wyrok sądu prawomocny, http://telewizjarepublika.pl/za-zarty-z-ukrainek-eska-rock-zaplaci-50-tys-zl-wyrok-sadu-prawomocny,10623. html [dostęp: 4.02.2016].

${ }^{20}$ Wojewódzki i Figurski bez kary. Są: To satyra, a nie szerzenie rasizmu, http://wiadomosci.dziennik.pl/media/artykuly/463757,wojewodzki-i-figurski-bez-kary-sad-to-satyra-a-nieszerzenie-rasizmu.html [dostęp: 20.02.2016].

${ }^{21}$ Artykuł E. Łętowskiej Zwodnicze uroki pokusy karania za hate speech został przedrukowany w pokonferencyjnej publikacji Helsińskiej Fundacji Praw Człowieka pt. Mowa nienawiści w Internecie: jak z niq walczyć?, red. D. Bychawska-Siniarska, D. Głowacka, Helsińska Fundacja Praw Człowieka, Warszawa 2013, s. 15-20. 
Interesujący proces o naruszenie dóbr osobistych toczył się niedawno przed Sądem Okręgowym w Łodzi ${ }^{22}$. Powódka to lekarka z 40-letnim stażem pracy, była dyrektor pabianickiego szpitala, znana z ekspresyjnego formułowania myśli. Kobieta uznała za obraźliwe satyryczne komentarze (fotomontaż z „dymkiem”, piosenka - parodia przeboju Koko Euro Spoko); utwory odnosiły się do naruszającego prawo zwolnienia ginekologów. Opublikował je tygodnik „Nowe Życie Pabianic"23.

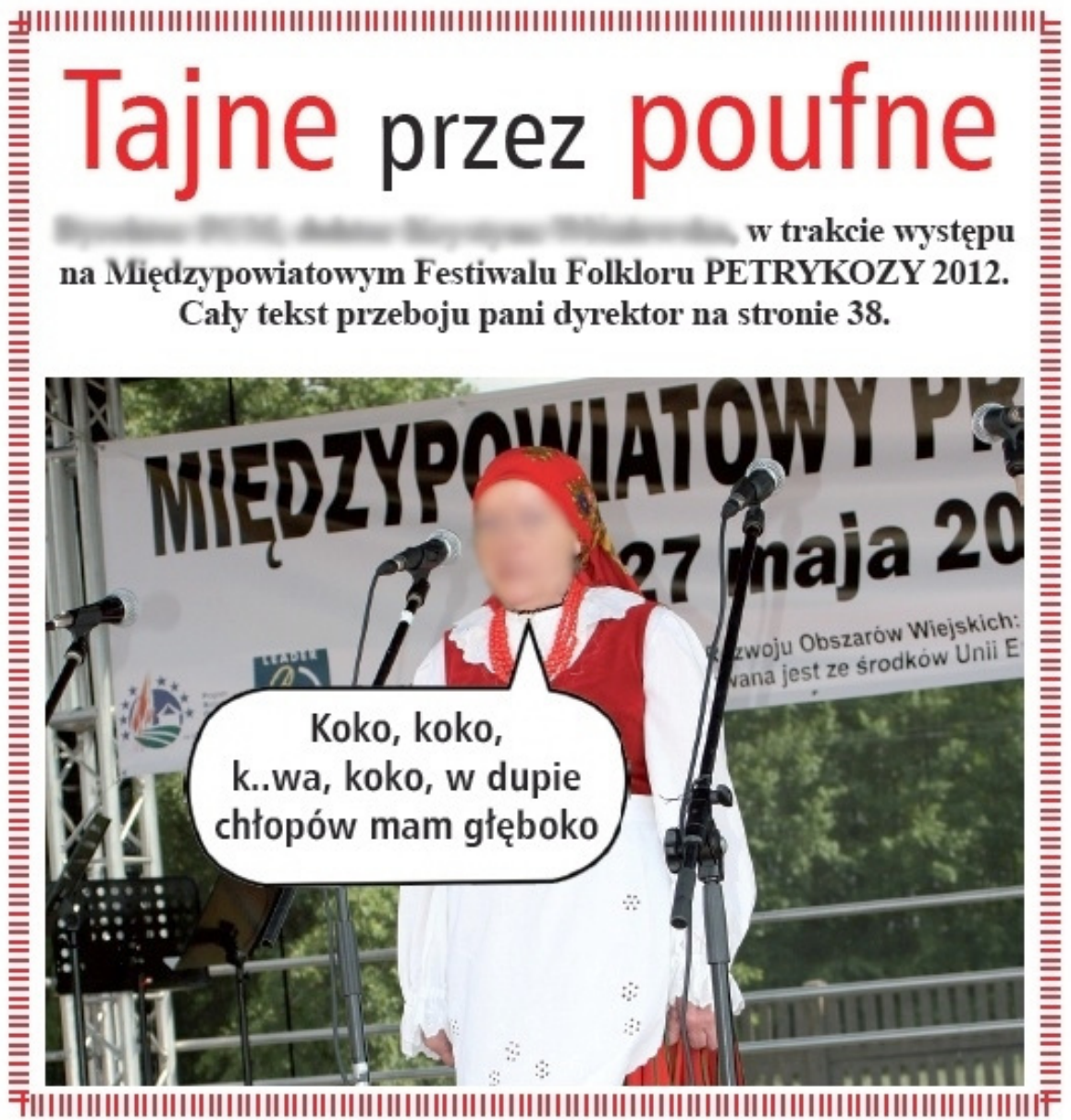

Fot. 2

Źródto: „Nowe Życie Pabianic” 2012, nr 27.

22 Sygnatura: II C 407/13.

23 „Nowe Życie Pabianic” 2012, nr 27, s. 2. 
Lekarka domagała się przeprosin i 24 tys. zł tytułem zadośćuczynienia. Obrona powódki w pozwie zaznaczyła m.in., iż:

zdjęcie to nie przedstawia mojej mocodawczyni, wedle jej oświadczenia. Zdjęcie także zawiera dymek o treści „Koko, koko, k...wa, koko, w dupie chłopów mam głęboko”, co ma stanowić wypowiedź Krystyny Wiśniewskiej. Treść tej wypowiedzi jest w oczywisty sposób wulgarna, wypowiedź posługuje się słowami uznawanymi powszechnie za wulgarne i których osoba kulturalna w rozmowie nie używa, to jest słowem „k...wa” i ,mieć w dupie”. Nawet jeżeli rubryka „Tajne przez poufne” ma mieć charakter satyryczny, w tym przypadku zostały ewidentnie przekroczone ramy satyry.

Sprawa w sądzie zyskała miano kokoprocesu. Sąd drugiej instancji nakazał przeprosić za chmurkę i piosenkę oraz zapłacić 12 tys. $\mathrm{zł}^{24}$. W uzasadnieniu podważono także interes społeczny. Gdyby jednak satyra miała dbać o interes społeczny, czyli dążyć do naprawy życia publicznego, racji bytu pozbawione zostałyby np. rubryki satyryczne ze strony Fusy plusy $i$ minusy (tygodnik „Polityka”).

Wspomniane „Nowe Życie Pabianic” w 2014 roku opisało, jak radny, zastępca przewodniczącego pabianickiego koła Platformy Obywatelskiej, dostał - od dyrektora Zarządu Dróg i Zieleni Miejskiej, innego wiceprzewodniczącego tego samego koła - zlecenie na projekt modernizacji szaletu miejskiego ${ }^{25}$. Radny zażądał przeprosin i wpłacenia w ciągu pięciu dni 15 tys. zł na cel społeczny oraz zagroził, że jeśli redakcja tego nie zrobi, skieruje sprawę do sądu. Grożący został obśmiany. Tematem kolejnych publikacji nie był już kontrowersyjny konkurs ofert, lecz przesadzona reakcja na tekst. Jak lepiej pokazać przesadę niż przez jej użycie?

W tygodniku ukazały się prześmiewcze przeprosiny:

Ja, Justyna Małycha, przepraszam, że ośmielam się realizować dziennikarską misję, polegającą na tropieniu, demaskowaniu i obnażaniu partyjnych układów oraz kolesiostwa. Przepraszam, że sprawuję funkcję kontrolną (do czego zresztą zobowiązuje mnie prawo prasowe) wobec radnych i wszystkich tych, których wynagrodzenia sponsorują podatnicy. Przepraszam, że nie lubię tałatajstwa, łapownictwa, arogancji, obłudy, nepotyzmu, kłamstwa i różnych kombinacji. Co ja sobie w ogóle myślę? ${ }^{26}$

Redakcja wygrała proces (nazwany kolokwialnie szaletgate) w sądzie pierwszej instancji, jednak Sąd Apelacyjny nie podszedł do felietonu jak do gatunku

\footnotetext{
${ }^{24}$ Sygnatura: ACa 1580/14.

${ }^{25}$ J. Małycha, Pic na szalet fotomontaż, „Nowe Życie Pabianic” 2014, nr 1, s. 5.

${ }^{26}$ J. Małycha, Przepraszam, że pisze, ,Nowe Życie Pabianic” 2014, nr 6, s. 7.
} 
satyrycznego i nakazał przeprosić na pierwszej stronie gazety. Uzasadniając wyrok, sąd stwierdził m.in.:

Tekst „Przepraszam, że piszę” nie dość, że zawiera szereg inwektyw, to bez odniesienia do konkretnych sytuacji świadczy o wyjątkowym braku profesjonalizmu dziennikarskiego, gdyż ani nie przekazuje żadnej informacji, ani nie stanowi rzetelnej krytyki, a jedynie narusza cudze dobra osobiste. Przy czym sąd przypomina, iż na mocy Prawa prasowego dziennikarz ma zachować szczególną staranność przy zbieraniu i wykorzystaniu materiałów prasowych, a zwłaszcza sprawdzić zgodność z prawdą uzyskanych wiadomości lub podać ich źródło 27.

Takie stwierdzenie ma cechy absurdu - przypisuje wymogi prawa prasowego odnośnie do staranności satyrze, która opiera się na przesadzie i fikcji, i nie jest zbiorem informacji, lecz stanowi specyficzną, przesadzoną ocenę sytuacji, osób, zjawisk. W tej sprawie została skierowana do Sądu Najwyższego skarga kasacyjna.

Styk przepisów przeciwdziałających cenzurze i chroniących interesy opisywanych osób zasługuje na to, by poświęcić mu więcej uwagi. Specyfika form satyrycznych winna stać się przedmiotem szerszej debaty w środowisku prawników i dziennikarzy. Razi mała wnikliwość sądów w badaniu gatunków satyrycznych, wyrażających bardzo szczególną formę krytyki. Ten brak dociekliwości przejawia się choćby w niepowoływaniu biegłych. Konsekwencje takiego stanu rzeczy są szkodliwe dla wolności słowa i twórczości artystycznej, jaką jest satyra. Kształtują się bowiem mechanizmy autocenzury czy wręcz unikania, jak w przypadku wydawców „Nowego Życia Pabianic”, którzy w ubiegłym roku wyeliminowali z łamów swojego pisma satyrę.

\section{Bibliografia}

[b.a.; b.t.], „Nowe Życie Pabianic” 2012, nr 27.

Hodak M., Satyryczne gatunki prasowe po 1989 roku, niepublikowana praca doktorska, Wydział Filologiczny UŁ, Łódź 2015.

Kozieł A., Publicystyka wizualna w prasie: karykatura, rysunek satyryczny, fotomontaż, [w:] Komunikacja wizualna $w$ prasie $i$ w mediach elektronicznych, red. K. Wolny-Zmorzyński, W. Furman, J. Snopek, K. Groń, Poltext, Warszawa 2013, s. 35-44.

Łętowska E., Zwodnicze uroki pokusy karania za hate speech, [w:] Mowa nienawiści w Internecie: jak z niq walczyć?, red. D. Bychawska-Siniarska, D. Głowacka, Helsińska Fundacja Praw Człowieka, Warszawa 2013, s. 15-20.

Małycha J., Pic na szalet fotomontaż, „Nowe Życie Pabianic” 2014, nr 1, s. 5.

Małycha J., Przepraszam, że piszę, „Nowe Życie Pabianic” 2014, nr 6, s. 7.

\footnotetext{
${ }^{27}$ Z pisemnego uzasadnienia wyroku z dnia 18 grudnia 2015 roku, sygn. akt I ACa 898/15.
} 
Słownik rodzajów i gatunków literackich, red. G. Gazda, wyd. 2, Wydawnictwo Naukowe PWN, Warszawa 2012.

Wasilewski P., Wolność prasowej wypowiedzi satyrycznej. Studium cywilistyczne na tle porównawczym, Wolters Kluwer Polska, Warszawa 2012.

Zwolińska K., Malicki Z., Mały stownik terminów plastycznych, Wiedza Powszechna, Warszawa 1974.

\section{Netografia}

Internauta „represjonowany” za żart z Kaczyńskich. Szef PO Donald Tusk powiedziat, że internauta z Elblaga - który rozesłat poczta elektronicznq..., http://wiadomosci.onet.pl/tablica/ internauta-represjonowany-za-zart-z-kaczynskich-sz,1666,270154,41022122,watek.html [dostęp: 29.01.2016].

Jakie granice satyry?, http://www.wprost.pl/ar/20125/Jakie-granice-satyry/ [dostęp: 30.01.2016].

Koniec procesu Tusk - Urban. Naczelny ,Nie” obśmiat wyrok, http://wiadomosci.dziennik.pl/media/artykuly/440852,koniec-procesu-tusk-urban.html [dostęp: 4.02.2016].

Nowa kampania spoleczna: „Wykreśl 212 kk”, http://wiadomosci.onet.pl/kraj/nowa-kampaniaspoleczna-wykresl-212-kk/hdd1b [dostęp: 29.01.2016].

Sadurski S., Satyra i paragraf, http://www.sadurski.com/satyra/paragraf.htm [dostęp: 10.02.2016].

Wojewódzki i Figurski bez kary. Sąd: To satyra, a nie szerzenie rasizmu, http://wiadomosci.dziennik.pl/media/artykuly/463757,wojewodzki-i-figurski-bez-kary-sad-to-satyra-a-nie-szerzenie-rasizmu.html [dostęp: 20.02.2016].

Za żarty z Ukrainek Eska Rock zapłaci 50 tys. zt. Wyrok sqdu prawomocny, http://telewizjarepublika.pl/za-zarty-z-ukrainek-eska-rock-zaplaci-50-tys-zl-wyrok-sadu-prawomocny,10623. html [dostęp: 4.02.2016].

\section{Ustawy}

Ustawa z 23 kwietnia 1964 roku Kodeks cywilny (Dz. U. Nr 16 poz. 93 ze zm.).

Ustawa z 6 czerwca 1997 roku Kodeks karny (Dz. U. z 1997 r. Nr 88 poz. 553 ze zm.).

Ustawa z 26 stycznia 1984 roku Prawo prasowe (Dz. U. 1984 Nr 5 poz. 24 ze zm.).

\section{Akta sądowe}

II C 407/13.

ACa 1580/14.

IACa 898/15. 
Magdalena Hodak

The Legal Consequences of Using a Satirical Style

(Summary)

Satire is a form of the presentation of reality which relies on distortion and deformation. The media make frequent use of satirical forms of expression. Freedom of expression, including satirical expression, is guaranteed in the Constitution and media law. On the other hand, the civil and penal law protect the individuals being criticized and satirized from unfair or spiteful targeting.

As far as the missions of freedom of speech and guardian-of-democracy of the media are concerned, article No. 212 of the Penal Code raises some serious doubts as to its undemocratic nature. The article introduces prison sentences as a punishment for libel/slander, which might be used by the politicians to silence dissident journalists. The Civil Law is not so restrictive, however, the very fact of being sued can seriously damage the financial condition of a given newspaper/ website, which in turn may lead to avoidance of tackling controversial issues and self-censorship.

It is surprising how poor courts are at analyzing satirical forms of expression, and how contradictory sentencing is in cases of a similar nature. The specificity of satirical forms of expression should become the subject of extensive debate among journalists and lawyers.

Keywords: satire, satirical style, law. 